\title{
Desulfonauticus submarinus gen. nov., sp. nov., a novel sulfate-reducing bacterium isolated from a deep-sea hydrothermal vent
}

\author{
Carine Audiffrin, Jean-Luc Cayol, Catherine Joulian, Laurence Casalot, \\ Pierre Thomas, Jean-Louis Garcia and Bernard Ollivier
}

Correspondence

Bernard Ollivier

ollivier@esil.univ-mrs.fr
IRD, UR 101 Extrêmophiles, IFR-BAIM, Universités de Provence et de la Méditerranée, ESIL, case 925, 163 avenue de la Méditerranée, 13288 Marseille cedex 09, France
Bacterial sulfate-reducers are widespread in marine, terrestrial and subterranean environments, where they contribute significantly with methanogens to the overall degradation of organic matter. In the last two decades, much attention has been paid by scientists to microbial communities living in deep environments, with particular emphasis on deep-sea hydrothermal vents (Chevaldonné et al., 1992; Jeanthon, 2000). Such environments are known to be inhabited by a wide range of mesophilic to hyperthermophilic microorganisms involved in the oxidation and/or reduction of sulfur compounds including sulfide, thiosulfate, sulfite and elemental sulfur (Jeanthon, 2000). Amongst these microorganisms, particularly aerobic sulfide-oxidizers, but also anaerobic sulfur-reducers, were recognized to be of ecological significance. Molecular ecological and microbiological studies of hydrothermal chimneys or sediments and of growth chambers deployed in hydrothermal vents (Burggraf et al., 1990; Jeanthon, 2000; Jeanthon et al., 2002; Reysenbach et al., 2000) have demonstrated the prevalence of thermophilic microbes that use (i) hydrogen as an electron donor and (ii) sulfur compounds (e.g., $S^{0}$, sulfate, thiosulfate) as terminal electron acceptors and their

The GenBank/EMBL/DDBJ accession numbers for the $16 \mathrm{~S}$ rDNA and dsr gene sequences of strain $6 N^{\top}$ are AF524933 (16S rDNA), AY187623 (dsrA) and AY187624 (dsrB). probable importance in hydrogen and sulfur metabolism in situ.

In contrast to the so-called 'moderately to hyperthermophilic sulfur-reducers', the community of sulfate-reducing bacteria, some of which are also able to reduce thiosulfate, sulfite and $S^{0}$, has been poorly studied. However, the dominance of sulfate-reducing bacteria in hydrothermal communities has been confirmed by measurements of sulfate-reduction activity in sediments (Elsgaard et al., 1994; Jorgensen et al., 1992) and by their repeated isolation from hydrothermal samples (Alazard et al., 2003; Elsgaard et al., 1995). Thermophilic sulfate- and/or sulfite-reducing members of the domain Archaea were found to be representative of these deep microbial communities. They include Archaeoglobus profundus (Burggraf et al., 1990), isolated from hydrothermal vents at Guaymas Basin, and Archaeoglobus veneficus (Huber et al., 1997), isolated from several chimney samples collected at the Mid-Atlantic Ridge $\left(23^{\circ} \mathrm{N}\right)$ and East-Pacific Rise $\left(9^{\circ} \mathrm{N}\right)$. Thermophilic and mesophilic representatives of the domain Bacteria include Thermodesulfobacterium hydrogeniphilum (Jeanthon et al., 2002), isolated from a deep-sea hydrothermal vent at Guaymas Basin, 'Desulfothermus naphthae' (Kuever et al., 2003; Rueter et al., 1994), also isolated from Guaymas Basin sediments, and Desulfovibrio hydrothermalis and 
Desulfovibrio profundus-like micro-organisms (Alazard et al., 2003), isolated from a deep-sea hydrothermal chimney sample collected on the $13^{\circ} \mathrm{N}$ East-Pacific Rise.

Here, we report the isolation of a novel hydrogenotrophic, thermophilic sulfate-reducer isolated from the same deep marine hydrothermal site from which Desulfovibrio hydrothermalis was isolated. Because of significant phylogenetic, phenotypic and genomic differences from sulfate-reducing bacteria within the subclass $\delta$-Proteobacteria, we propose to assign this isolate to a new genus and species within the family Desulfohalobiaceae, Desulfonauticus submarinus gen. nov., sp. nov.

Nine strains were isolated from various matrixes of Alvinella stored in glycerol/sea water $(80 / 20, \mathrm{v} / \mathrm{v})$ at $-80^{\circ} \mathrm{C}$ and of Riftia stored in sea water at $4{ }^{\circ} \mathrm{C}$ until processing. The samples were collected during the AMISTAD cruise by the deep-submergence vehicle Nautile in June 1999 from the Grandbonum vent site at $13^{\circ} \mathrm{N}, 103^{\circ} 56^{\prime} \mathrm{W}$ along the EastPacific Rise at $2600 \mathrm{~m}$ depth. Enrichments were performed using sulfate-reducing bacteria (SRB) growth medium containing $\left(\mathrm{l}^{-1}\right.$ distilled water): $1 \mathrm{~g} \mathrm{NH}_{4} \mathrm{Cl}, 0.3 \mathrm{~g} \mathrm{~K}_{2} \mathrm{HPO}_{4}$, $0.3 \mathrm{~g} \mathrm{KH} \mathrm{KO}_{4}, 1.8 \mathrm{~g} \mathrm{MgCl}_{2} .6 \mathrm{H}_{2} \mathrm{O}, 0.4 \mathrm{~g} \mathrm{CaCl}_{2} .2 \mathrm{H}_{2} \mathrm{O}$, $23 \mathrm{~g} \mathrm{NaCl}, 0 \cdot 1 \mathrm{~g} \mathrm{KCl}, 3 \mathrm{~g} \mathrm{Na}_{2} \mathrm{SO}_{4}, 1 \mathrm{~g}$ sodium acetate dihydrate, $0.5 \mathrm{~g}$ cysteine hydrochloride, $2 \mathrm{~g}$ yeast extract (Difco), $2 \mathrm{~g}$ bio-Trypticase (bioMérieux), $10 \mathrm{ml}$ traceelement solution (Widdel \& Pfennig, 1981; Imhoff-Stuckle \& Pfennig, 1983) and $1 \mathrm{mg}$ resazurin. The $\mathrm{pH}$ was adjusted to $7 \cdot 0$ with $10 \mathrm{M} \mathrm{KOH}$ and the medium was boiled under a stream of $\mathrm{O}_{2}$-free $\mathrm{N}_{2}$ gas and cooled to room temperature. Aliquots were then dispensed into Hungate tubes $(5 \mathrm{ml})$ or serum bottles $(20 \mathrm{ml})$ under a stream of $\mathrm{N}_{2} / \mathrm{CO}_{2}(80: 20$, $\mathrm{v} / \mathrm{v}$ ) and the vessels were autoclaved for $45 \mathrm{~min}$ at $110^{\circ} \mathrm{C}$. Prior to inoculation, $\mathrm{Na}_{2} \mathrm{~S} .9 \mathrm{H}_{2} \mathrm{O}$ and $\mathrm{NaHCO}_{3}$ were injected from sterile stock solutions to obtain respective final concentrations of 0.04 and $0 \cdot 2 \%(\mathrm{w} / \mathrm{v})$. The matrixes of Riftia and Alvinella were inoculated in $20 \mathrm{ml}$ SRB medium and incubated at 45 and $55^{\circ} \mathrm{C}$ with agitation under an atmosphere of $\mathrm{H}_{2} / \mathrm{CO}_{2}(80: 20,2$ bar) to initiate enrichment cultures. Isolation was performed in modified SRB medium $\left[\mathrm{MgCl}_{2}, \mathrm{CaCl}_{2}, \mathrm{KCl}\right.$ and $\mathrm{NaCl}$ were replaced by sea salts (Sigma; $30 \mathrm{~g} \mathrm{l}^{-1}$ ), the concentrations of yeast extract and bio-Trypticase were respectively lowered to $0 \cdot 3$ and $0.2 \mathrm{~g} \mathrm{l}^{-1}$ and $0.2 \mathrm{ml}$ of the vitamin solutions of Balch et al. (1979) and Widdel \& Pfennig (1981) were added per litre medium]. The culture was purified by repeated use of the roll-tube method (Hungate, 1969) with medium solidified with $2 \%(\mathrm{w} / \mathrm{v})$ Noble agar (Difco). Several colonies obtained were picked and cultured in the culture medium. The process of isolation was repeated several times until the isolates were deemed to be axenic.

$\mathrm{pH}$, temperature and $\mathrm{NaCl}$ ranges for growth were determined as described previously (Hernandez-Eugenio et al., 2000) using SRB medium with the addition of vitamin solutions (Balch et al., 1979; Pfennig \& Widdel, 1981). Substrates were tested at a final concentration of $20 \mathrm{mM}$ in SRB medium. To test for electron acceptors, sodium thiosulfate, sodium sulfate, sodium sulfite, sodium nitrate and elemental sulfur were added to the medium at respective final concentrations of 20,20, 2 and $10 \mathrm{mM}$ and $2 \%(\mathrm{w} / \mathrm{v})$. Phase-contrast microscopy (model Eclipse E600; Nikon) was used for routine examination of the cultures and to obtain photomicrographs. For electron microscopy, thin sections were prepared as described by Fardeau et al. (1997). Photomicrographs were taken with a Hitachi model H600 electron microscope at $75 \mathrm{kV}$. Unless otherwise indicated, duplicate culture tubes were used throughout these studies. Growth was measured by inserting tubes directly into a model Cary 50 Scan spectrophotometer (Varian) and measuring the $\mathrm{OD}_{580}$. Sulfide was determined photometrically as colloidal CuS by using the method of CordRuwisch (1985). Fermentation products were determined as described by Fardeau et al. (1993). Desulfoviridin was determined as described by Postgate (1959).

The $\mathrm{G}+\mathrm{C}$ content of DNA was determined at the Deutsche Sammlung von Mikroorganismen und Zellkulturen (DSMZ), Braunschweig, Germany, using HPLC as described previously (Hernandez-Eugenio et al., 2000). Genomic DNA was extracted using the Wizard Genomic DNA purification kit (Promega), according to the manufacturer's protocol. DNA extracts were stored at $-20^{\circ} \mathrm{C}$ in Tris/ $\mathrm{HCl}$ $(10 \mathrm{mM}, \mathrm{pH} 8 \cdot 0)$. The $16 \mathrm{~S}$ rRNA gene was amplified with the primers Fd1 (5'-AGAGTTTGATCCTGGCTCAG-3') and Rd1 (5'-AAGGAGGTGATCCAGCC- $\left.3^{\prime}\right)$ and the following reaction conditions: $1 \mathrm{~min}$ at $94^{\circ} \mathrm{C}, 30$ cycles of $30 \mathrm{~s}$ at $94^{\circ} \mathrm{C}, 1 \mathrm{~min}$ at $55^{\circ} \mathrm{C}$ and $2 \mathrm{~min}$ at $72^{\circ} \mathrm{C}$ and a final extension of $10 \mathrm{~min}$ at $72^{\circ} \mathrm{C}$. The genes encoding DSR ( $\alpha$ - and $\beta$-subunits) were amplified with the primers DSR1F (5'-ACSCACTGGAAGCACG-3') and DSR4R (5'-GTGTAGCAGTTACCGCA-3') (Wagner et al., 1998) and the following reaction conditions: $1 \mathrm{~min}$ at $94^{\circ} \mathrm{C}, 45$ cycles of $30 \mathrm{~s}$ at $94^{\circ} \mathrm{C}, 1 \mathrm{~min}$ at $45 \cdot 7^{\circ} \mathrm{C}$ and $3 \mathrm{~min}$ at $72^{\circ} \mathrm{C}$ and a final extension of $10 \mathrm{~min}$ at $72^{\circ} \mathrm{C}$. PCR products were purified with the Nucleo Spin extract kit (Macherey Nagel) and cloned using the pGEM-T-easy cloning kit (Promega), according to the manufacturers' protocols. The clone libraries were screened by direct PCR amplification from a colony using the vector-specific primers SP6 $\left(5^{\prime}\right.$-ATTTAGGTGACACTATAGAA-3') and T7 (5'TAATACGACTCACTATAGGG- $3^{\prime}$ ) and the following reaction conditions: $2 \mathrm{~min}$ at $96^{\circ} \mathrm{C}, 40$ cycles of $30 \mathrm{~s}$ at $94^{\circ} \mathrm{C}, 1 \mathrm{~min}$ at $55^{\circ} \mathrm{C}$ and $3 \mathrm{~min}$ at $72^{\circ} \mathrm{C}$ and a final extension of 10 min at $72^{\circ} \mathrm{C}$. Plasmids containing inserts of the correct length were isolated using the Wizard Plus SV Minipreps DNA purification system (Promega) according to the manufacturer's protocol. Purified plasmids were sent for sequencing to Genome Express. The nucleotide sequence of the 16S rRNA gene and the amino acid sequence deduced from the nucleotide sequence of the DSR genes were aligned manually with reference sequences of various members of the genus Desulfovibrio using the sequence alignment editor BioEdit (Hall, 1999). Reference sequences were obtained from the Ribosomal Database Project II (Maidak et al., 2001), EMBL and GenBank databases (Benson et al., 1999). 
Positions of sequence and alignment uncertainty were omitted from the analysis. Pairwise evolutionary distances based on 1111 unambiguous nucleotides (16S rRNA gene) and on 428 unambiguous amino acids (DSR genes) were computed by using respectively the Jukes \& Cantor (1969) method and the Kimura (1980) method. Dendrograms were constructed by using the neighbour-joining method (Saitou \& Nei, 1987). Confidence in the tree topology was determined by bootstrap analysis using 100 resamplings of the sequences (Felsenstein, 1985).

The enrichment medium used in the absence of sulfate in this study was first designed for the isolation of methanogens. Because of significant sulfide production in some of these enrichments, we decided to investigate the presence of novel thermophilic sulfate-reducing bacteria. Sulfatereducing enrichment cultures were obtained after 3 weeks incubation at 45 and $55^{\circ} \mathrm{C}$. Microscopic observations revealed the presence of long, motile, curved rods. The enrichment was subcultured in Hungate roll tubes. Single, brown, discus-shaped colonies (1 mm diameter) that developed after 45 days incubation at 45 and $55^{\circ} \mathrm{C}$ were picked and serially diluted in roll tubes before the culture was considered pure. Five strains $\left(7 \mathrm{~V}, 7 \mathrm{~B}, 6 \mathrm{~N}^{\mathrm{T}}, 8 \mathrm{~V}, 8 \mathrm{~B}\right)$ were isolated at $45^{\circ} \mathrm{C}$ and four strains $(21 \mathrm{G}, 32 \mathrm{G}, 41 \mathrm{G}, 52 \mathrm{G})$ were isolated at $55^{\circ} \mathrm{C}$. The purity of these strains was confirmed by morphological homogeneity observed under a phasecontrast microscope and by the absence of growth in liquid sulfate-free SRB medium supplemented with $20 \mathrm{mM}$ glucose under aerobic or anaerobic conditions. The nine strains were found to be phylogenetically very similar. Strain $6 \mathrm{~N}^{\mathrm{T}}$ was characterized further.

Microscopic observations revealed that cells of strain $6 \mathrm{~N}^{\mathrm{T}}$ were rod-shaped, 5-6 $\mu \mathrm{m}$ long and $0 \cdot 35-0 \cdot 50 \mu \mathrm{m}$ wide and occurred mainly singly (Fig. 1a). They were motile with one polar flagellum (Fig. 1b). Sporulation was never observed. Electron microscopy of ultrathin sections of cells indicated the presence of a thin tripartite cell wall analogous to an outer membrane covering a clear periplasm (Fig. 1c). Strain $6 \mathrm{~N}^{\mathrm{T}}$ was strictly anaerobic, growing optimally in basal SRB medium containing $\mathrm{H}_{2}+\mathrm{CO}_{2}$ and sulfate at $45^{\circ} \mathrm{C}$ (temperature growth range between 30 and $60^{\circ} \mathrm{C}$ ) and $\mathrm{pH} 7 \cdot 0$. It was slightly halophilic, growing optimally in the presence of $2 \%(\mathrm{w} / \mathrm{v}) \mathrm{NaCl}$, the upper limit for growth being $5 \%$ $\mathrm{NaCl}$. Under optimal growth conditions, the mean doubling time was about $12 \mathrm{~h}$. Strain $6 \mathrm{~N}^{\mathrm{T}}$ used only $\mathrm{H}_{2}+\mathrm{CO}_{2}$ in the presence of sulfate as electron acceptor and acetate as carbon source. Growth on formate and acetate (carbon source) was only obtained when $\mathrm{NaCl}, \mathrm{KCl}, \mathrm{MgCl}_{2}$ and $\mathrm{CaCl}_{2}$ were replaced by sea salts $\left(30 \mathrm{~g} \mathrm{l}^{-1}\right)$. No growth was observed on the following substrates using sulfate as electron acceptor: lactate, fumarate, malate, succinate, glycerol, acetate, propionate, butyrate, methanol, ethanol, fructose, glucose, mannose, rhamnose, sucrose, choline, Casamino acids, yeast extract and bio-Trypticase. Sulfate, thiosulfate, sulfite and elemental sulfur served as electron acceptors.

It is clear from ecological, molecular ecological and
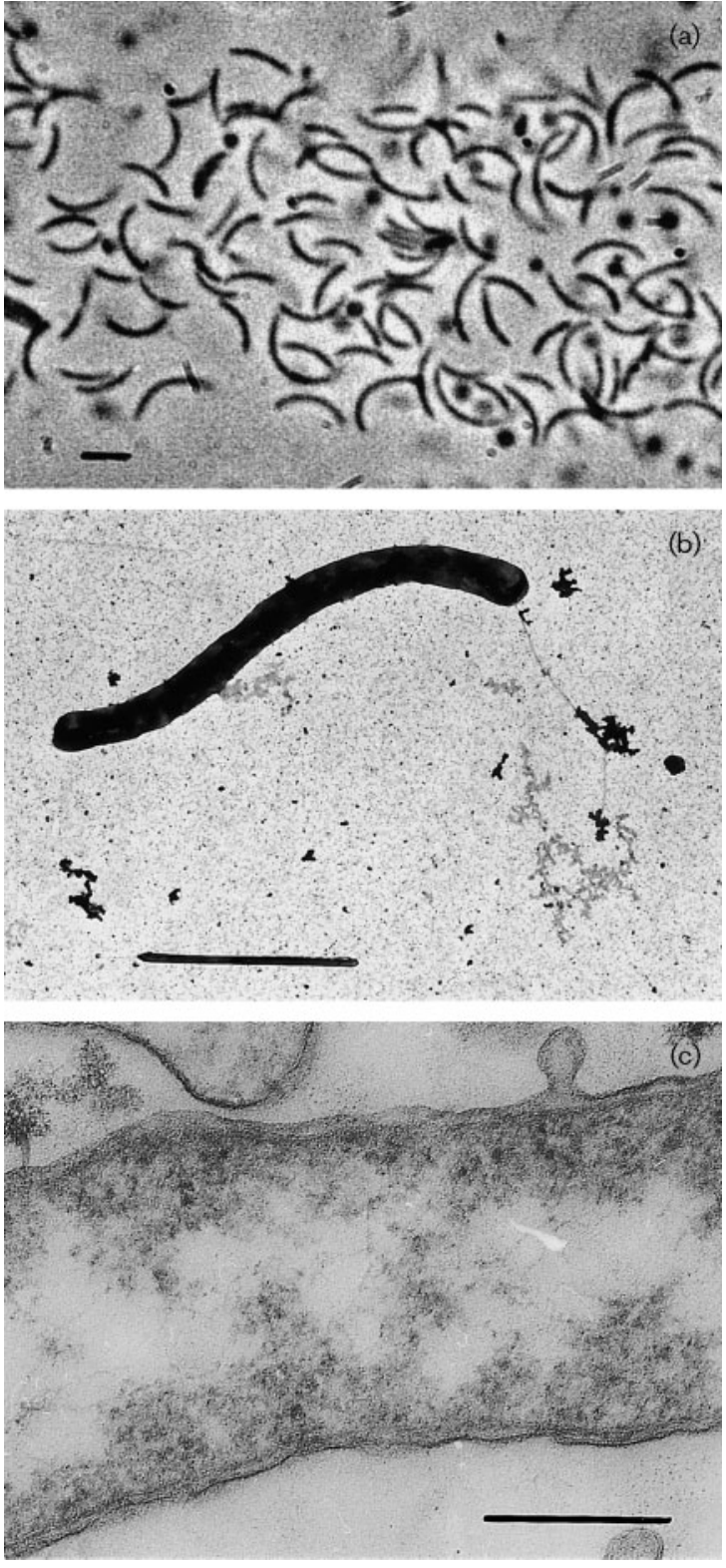

Fig. 1. (a)-(b) Phase-contrast photomicrograph (a) and electron transmission micrograph (b) of strain $6 \mathrm{~N}^{\top}$ grown with hydrogen as an energy source. Bars, $2 \mu \mathrm{m}$. (c) Electron micrograph of an ultrathin section of a cell of strain $6 \mathrm{~N}^{\top}$ showing the multilayered cell wall. Bar, $0 \cdot 2 \mu \mathrm{m}$.

microbiological studies that sulfate-reducers, together with sulfur-reducers, play an important role in the hydrogen and/or sulfur metabolism within deep-sea hydrothermalvent environments (Jeanthon, 2000). Although the biodiversity of sulfur-reducers has been widely studied in these deep ecosystems, there are few reports on the isolation and characterization of sulfate- and/or sulfite-reducers (Alazard et al., 2003; Burggraf et al., 1990; Elsgaard et al., 1995; Huber et al., 1997; Jeanthon et al., 2002; Rueter et al., 1994). Here, we describe a novel thermophilic sulfate-reducer (strain 


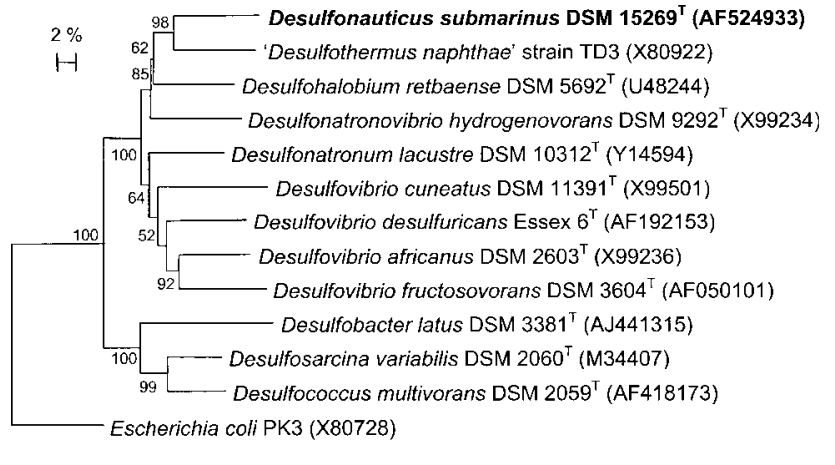

Fig. 2. Phylogenetic tree based on $16 \mathrm{~S}$ rRNA gene sequence comparison indicating the position of strain $6 \mathrm{~N}^{\top}$ amongst the closest members of the family Desulfohalobiaceae and genera Desulfomicrobium and Desulfovibrio. Sequence accession numbers are given in parentheses. Bootstrap values, expressed as percentages of 100 replications, are shown at branching points. The 16S rRNA gene of Escherichia coli PK3 was used as the outgroup. Bar, 2 substitutions per 100 nucleotides.

$6 \mathrm{~N}^{\mathrm{T}}$ ), isolated from various matrixes of Alvinella and Riftia. Analysis of the almost complete sequence (1111 bp) of the $16 \mathrm{~S}$ rRNA gene of strain $6 \mathrm{~N}^{\mathrm{T}}$ revealed that this novel isolate groups with members of the family Desulfohalobiaceae (Kuever et al., 2003) in the $\delta$-subclass of the Proteobacteria and is related to Desulfonatronovibrio hydrogenovorans (similarity $86.5 \%$ ) (Fig. 2). The G $+\mathrm{C}$ content of DNA of strain $6 \mathrm{~N}^{\mathrm{T}}$ was $34 \cdot 4 \mathrm{~mol} \%$. The phylogeny derived from 428 amino acids of DSR was congruent with the phylogeny derived from the 16S rRNA gene and supported the phylogenetic position of strain $6 \mathrm{~N}^{\mathrm{T}}$ within the family Desulfohalobiaceae, its closest relative being Desulfonatronovibrio hydrogenovorans (Fig. 3). This family comprises the genera Desulfohalobium (Desulfohalobium retbaense) (Ollivier et al., 1991), Desulfonatronovibrio (Desulfonatronovibrio hydrogenovorans) (Zhilina et al.,
1997) and 'Desulfothermus' ('Desulfothermus naphthae') (Kuever et al., 2003; Rueter et al., 1994). In contrast to strain $6 \mathrm{~N}^{\mathrm{T}}$, 'Desulfothermus naphthae', the only thermophilic member of the family Desulfohalobiaceae, is unable to use hydrogen and performs the complete oxidation of organic substrates (hydrocarbons). Desulfohalobium retbaense differed markedly from strain $6 \mathrm{~N}^{\mathrm{T}}$ by (i) using not only hydrogen but also lactate and ethanol and (ii) growing in a moderate range of salinity. Finally, Desulfonatronovibrio hydrogenovorans is a non-halophilic, mesophilic, sulfatereducing bacterium that grows optimally in alkaline conditions. In this respect, there are numerous phenotypic, genomic and phylogenetic differences (Table 1) between strain $6 \mathrm{~N}^{\mathrm{T}}$ and members of family Desulfohalobiaceae that warrant its assignment to a new genus of the family.

Studies on the diversity of DSR genes in the bacterial community associated with the back of Alvinella pompejana suggested a prominent role for anaerobic sulfate-reducing bacteria in the ecology of this worm (Cottrell \& Cary, 1999). The DSR genes of Desulfovibrio gigas, Desulfobacterium autotrophicum and Desulfobacter latus were found to be the closest relatives of the clones analysed (Cottrell \& Cary, 1999). DSR genes similar to that of strain $6 \mathrm{~N}^{\mathrm{T}}$ were not recovered from these molecular studies, suggesting that the isolate might inhabit only the matrix of Alvinella. Interestingly, strain $6 \mathrm{~N}^{\mathrm{T}}$, isolated from various matrixes of Alvinella but also of Riftia on the $13^{\circ} \mathrm{N}$ East-Pacific Rise, uses mainly hydrogen as an energy source (formate was poorly used), thus suggesting that its metabolic role in hydrothermal vents is probably limited to the oxidation of this gaseous compound, which can be (i) produced by several deep mineral reactions (Devereux \& Stahl, 1993; Stetter et al., 1993) and (ii) emitted from smokers. Such hydrogenotrophic activity renders strain $6 \mathrm{~N}^{\mathrm{T}}$ an important protagonist within the biogeochemistry but also in detoxification processes within deep-sea hydrothermal vents. In contrast to the recently isolated Thermodesulfobacterium hydrogeniphilum (Jeanthon et al., 2002),

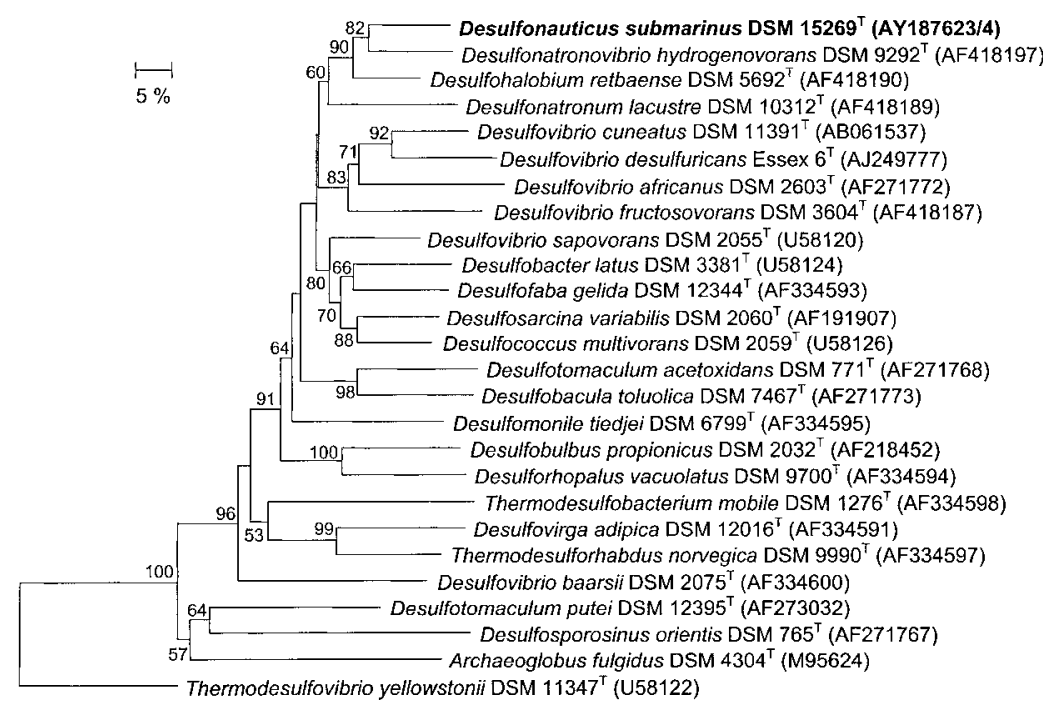

Fig. 3. Phylogenetic tree based on comparison of deduced DSR amino acid sequences indicating the position of strain $6 \mathrm{~N}^{\top}$ amongst the closest members of the family Desulfohalobiaceae and genera Desulfomicrobium and Desulfovibrio. Nucleotide sequence accession numbers from which the amino acid sequences were deduced are given in parentheses. Bootstrap values, expressed as percentages of 100 replications, are shown at branching points. The DSR amino acid sequence of Thermodesulfovibrio yellowstonii DSM $11347^{\top}$ was used as the outgroup. Bar, 5 substitutions per 100 amino acids. 
Table 1. Physiological characteristics of strain $6 \mathrm{~N}^{\top}$ and its closest relatives in the family Desulfohalobiaceae

Taxa: 1, strain $6 \mathrm{~N}^{\mathrm{T}} ; 2$, Desulfonatronovibrio hydrogenovorans (data from Zhilina et al., 1997); 3, Desulfohalobium retbaense (Ollivier et al., 1991); 4, 'Desulfothermus naphthae' (Kuever et al., 2003). ND, Not determined.

\begin{tabular}{|c|c|c|c|c|}
\hline Characteristic & 1 & 2 & 3 & 4 \\
\hline \multicolumn{5}{|c|}{ Temperature for growth $\left({ }^{\circ} \mathrm{C}\right)$ : } \\
\hline Optimum & 45 & 37 & $37-40$ & $60-65$ \\
\hline \multicolumn{5}{|c|}{$\mathrm{NaCl}$ concentration for growth (\%): } \\
\hline Range & $0-5$ & $1-12$ & $3-24$ & ND \\
\hline Reduction of $S^{0}$ & + & - & + & ND \\
\hline Substrates used & $\mathrm{H}_{2}+\mathrm{CO}_{2}$ & $\begin{array}{l}\mathrm{H}_{2}+\mathrm{CO}_{2} \\
\quad \text { formate }\end{array}$ & $\begin{array}{l}\text { Lactate, pyruvate, } \\
\text { ethanol }\end{array}$ & $\begin{array}{l}\text { Alkanes }\left(\mathrm{C}_{6}-\mathrm{C}_{14}\right) \\
\text { fatty acids }\left(\mathrm{C}_{4}-\mathrm{C}_{18}\right)\end{array}$ \\
\hline $\mathrm{G}+\mathrm{C}$ content $(\mathrm{mol} \%)$ & $34 \cdot 4$ & $48 \cdot 6$ & 57 & $37 \cdot 4$ \\
\hline
\end{tabular}

strain $6 \mathrm{~N}^{\mathrm{T}}$ also shows its perfect adaptation to the physicochemical conditions prevailing in deep-sea hydrothermal environments through its use of not only sulfate, but also thiosulfate, sulfite and $S^{0}$ as terminal electron acceptors, these sulfur compounds being commonly found in hydrothermal fluids (Jannasch \& Mottl, 1985). As noted above, because of its significant phenotypic, genotypic and phylogenetic characteristics, we propose the assignment of strain $6 \mathrm{~N}^{\mathrm{T}}$ to a new genus and species, Desulfonauticus submarinus gen. nov., sp. nov.

\section{Description of Desulfonauticus gen. nov.}

Desulfonauticus (De.sul'fo.nau'ti.cus. L. pref. de from; L. n. sulfur sulfur; N.L. pref. Desulfo- desulfuricating, use to characterize a dissimilatory sulfate-reducing prokaryote; L. adj. nauticus nautical; N.L. masc. n. Desulfonauticus a marine sulfate-reducer).

Cells are curved rods, motile with one polar flagellum, Gram-negative. Moderate thermophile, neutrophile and slightly halotolerant. In the presence of sulfate, only hydrogen plus acetate (carbon source) serve as growth substrates. Sulfate, thiosulfate, sulfite and elemental sulfur are utilized as electron acceptors. The $\mathrm{G}+\mathrm{C}$ content of DNA of the type strain of the type species is $34 \mathrm{~mol} \%$ as determined by HPLC. The type species is Desulfonauticus submarinus.

\section{Description of Desulfonauticus submarinus sp. nov.}

Desulfonauticus submarinus (sub.ma'ri.nus. L. pref. subunder; L. adj. marinus marine; N.L. adj. submarinus from a submarine area).

Cells are curved rods $(5-6 \times 0 \cdot 35-0 \cdot 50 \mu \mathrm{m})$, motile with one polar flagellum, Gram-negative. The temperature range for growth is $30-60{ }^{\circ} \mathrm{C}$, the optimum being $45^{\circ} \mathrm{C}$. The optimum $\mathrm{pH}$ is $7 \cdot 0$. The optimum $\mathrm{NaCl}$ concentration for growth is $2 \%$ (range $0-5 \%$ ). In the presence of sulfate, hydrogen plus acetate (carbon source) serve as growth substrate. Formate plus acetate (carbon source) used slowly when $\mathrm{MgCl}_{2}, \mathrm{CaCl}_{2}, \mathrm{KCl}$ and $\mathrm{NaCl}$ are replaced by sea salts $\left(30 \mathrm{~g} \mathrm{l}^{-1}\right)$. Lactate, fumarate, malate, succinate, glycerol, acetate, propionate, butyrate, methanol, ethanol, fructose, glucose, mannose, rhamnose, sucrose, choline, Casamino acids, yeast extract and bio-Trypticase are not used. Sulfate, thiosulfate, sulfite and elemental sulfur are utilized as electron acceptors. The $\mathrm{G}+\mathrm{C}$ content of DNA of the type strain is $34.4 \mathrm{~mol} \%$, as determined by HPLC.

The type strain, $6 \mathrm{~N}^{\mathrm{T}}$ ( = DSM $\left.15269^{\mathrm{T}}=\mathrm{CIP} 107713^{\mathrm{T}}\right)$, was isolated from matrixes of Riftia and Alvinella in the $13^{\circ} \mathrm{N}$ East-Pacific Rise at a depth of $2600 \mathrm{~m}$.

\section{Acknowledgements}

This work was supported by grants from the European Fifth Program for RTD (EVK1-CT 1999-00033) and from the BRGM (France). The AMISTAD cruise was organized by the Centre National de la Recherche Scientifique. We thank C. Jeanthon and D. Prieur for their kind invitation to join the cruise. We thank the captain and crew of the R/V l'Atalante and especially the pilots of the DSV Nautile for their essential roles in the collection of samples. Many thanks to M.-L. Fardeau for her technical assistance.

\section{References}

Alazard, D., Dukan, S., Urios, A., Verhé, F., Bouabida, N., Morel, F., Thomas, P., Garcia, J.-L. \& Ollivier, B. (2003). Desulfovibrio hydrothermalis sp. nov., a novel sulfate-reducing bacterium isolated from hydrothermal vents. Int J Syst Evol Microbiol 53, 173-178.

Balch, W. E., Fox, G. E., Magrum, R. J., Woese, C. R. \& Wolfe, R. S. (1979). Methanogens: reevaluation of a unique biological group. Microbiol Rev 43, 260-296.

Benson, D. A., Boguski, M. S., Lipman, D. J., Ostell, J., Ouellette, B. F., Rapp, B. A. \& Wheeler, D. L. (1999). GenBank. Nucleic Acids Res 27, 12-17. 
Burggraf, S., Jannasch, H. W., Nicolaus, B. \& Stetter, K. O. (1990). Archaeoglobus profundus sp. nov., represents a new species within the sulfur-reducing Archaebacteria. Syst Appl Microbiol 13, 24-28.

Chevaldonné, P., Desbruyères, D. \& Childress, J. J. (1992). Some like it hot... and some even hotter. Nature 359, 593-594.

Cord-Ruwisch, R. (1985). A quick method for the determination of dissolved and precipitated sulfides in cultures of sulfate-reducing bacteria. J Microbiol Methods 4, 33-36.

Cottrell, M. T. \& Cary, S. C. (1999). Diversity of dissimilatory bisulfite reductase genes of bacteria associated with the deep-sea hydrothermal vent polychaete annelid Alvinella pompejana. Appl Environ Microbiol 65, 1127-1132.

Devereux, R. \& Stahl, D. A. (1993). Phylogeny of sulfate-reducing bacteria and a perspective for analyzing their natural communities. In The Sulfate-Reducing Bacteria: Contemporary Perspectives, pp. 131160. Edited by J. M. Odom \& R. Singleton. New York: Springer.

Elsgaard, L., Isaksen, M. F., Jørgensen, B. B., Alayse, A.-M. \& Jannasch, H. W. (1994). Microbial sulfate reduction in deep-sea sediments at Guaymas Basin hydrothermal vent area: influence of temperature and substrates. Geochim Cosmochim Acta 58, $3335-3343$.

Elsgaard, L., Guezennec, J., Benbouzid-Rollet, N. \& Prieur, D. (1995). Mesophilic sulfate-reducing bacteria from three deep-sea hydrothermal vent sites. Oceanol Acta 18, 95-104.

Fardeau, M.-L., Cayol, J.-L., Magot, M. \& Ollivier, B. (1993). $\mathrm{H}_{2}$ oxidation in the presence of thiosulfate by a Thermoanaerobacter strain isolated from an oil-producing well. FEMS Microbiol Lett 13, 327-332.

Fardeau, M.-L., Ollivier, B., Patel, B. K. C., Magot, M., Thomas, P., Rimbault, A., Rocchiccioli, F. \& Garcia, J.-L. (1997). Thermotoga hypogea sp. nov., a xylanolytic, thermophilic bacterium from an oilproducing well. Int J Syst Bacteriol 47, 1013-1019.

Felsenstein, J. (1985). Confidence limits on phylogenies: an approach using the bootstrap. Evolution 39, 783-791.

Hall, T. A. (1999). BioEdit: a user-friendly biological sequence alignment editor and analysis program for Windows 95/98/NT. Nucleic Acids Symp Ser 41, 95-98.

Hernandez-Eugenio, G., Fardeau, M.-L., Patel, B. K. C., Macarie, H., Garcia, J.-L. \& Ollivier, B. (2000). Desulfovibrio mexicanus sp. nov., a sulfate-reducing bacterium isolated from an upflow anaerobic sludge blanket (UASB) reactor treating cheese wastewaters. Anaerobe 6, 305-312.

Huber, H., Jannasch, H., Rachel, R., Fuchs, T. \& Stetter, K. O. (1997). Archaeoglobus veneficus sp. nov., a novel facultative chemolithotrophic hyperthermophilic sulfite reducer, isolated from abyssal black smokers. Syst Appl Microbiol 20, 374-380.

Hungate, R. E. (1969). A roll tube method for the cultivation of strict anaerobes. Methods Microbiol 3B, 117-132.

Imhoff-Stuckle, D. \& Pfennig, N. (1983). Isolation and characterization of a nicotinic acid-degrading sulfate-reducing bacterium, Desulfococcus niacini sp. nov. Arch Microbiol 136, 194-198.

Jannasch, H. W. \& Mottl, J. (1985). Geomicrobiology and deep sea hydrothermal vents. Science 229, 717-725.

Jeanthon, C. (2000). Molecular ecology of hydrothermal vent microbial communities. Antonie van Leeuwenhoek 77, 117-133.

Jeanthon, C., L'Haridon, S., Cueff, V., Banta, A., Reysenbach, A.-L. \& Prieur, D. (2002). Thermodesulfobacterium hydrogeniphilum sp. nov., a thermophilic, chemolithoautotrophic, sulfate-reducing bacterium isolated from a deep-sea hydrothermal vent at Guaymas Basin, and emendation of the genus Thermodesulfobacterium. Int J Syst Evol Microbiol 52, 765-772.

Jorgensen, B., Isaksen, M. F. \& Jannasch, H. W. (1992). Bacterial sulfate reduction above $100{ }^{\circ} \mathrm{C}$ in deep-sea hydrothermal vent sediments. Science 258, 1756-1757.

Jukes, T. H. \& Cantor, C. R. (1969). Evolution of protein molecules. In Mammalian Protein Metabolism, pp. 21-132. Edited by H. N. Munro. New York: Academic Press.

Kimura, M. (1980). A simple model for estimating evolutionary rates of base substitutions through comparative studies of nucleotide sequences. J Mol Evol 16, 111-120.

Kuever, J., Rainey, F. A. \& Widdel, F. (2003). Family Desulfohalobiaceae. In Bergey's Manual of Systematic Bacteriology, 2nd edn, vol. 2. Edited by G. M. Garrity. New York: Springer (in press).

Maidak, B. L., Cole, J. R., Lilburn, T. G. \& 7 other authors (2001). The RDP-II (Ribosomal Database Project). Nucleic Acids Res 29, 173-174.

Ollivier, B., Hatchikian, C. E., Prensier, G., Guezennec, J. \& Garcia, J.-L. (1991). Desulfohalobium retbaense gen. nov., sp. nov., a halophilic sulfate-reducing bacterium from sediments of a hypersaline lake in Senegal. Int J Syst Bacteriol 41, 74-81.

Pfennig, N. \& Widdel, F. (1981). Ecology and physiology of some anaerobic bacteria from the microbial sulfur cycle. In Biology of Inorganic Nitrogen and Sulfur, pp. 169-177. Edited by H. Bothe \& A. Trebst. Berlin: Springer.

Postgate, J. R. (1959). A diagnostic reaction of Desulphovibrio desulphuricans. Nature 183, 481-482.

Reysenbach, A. L., Longnecker, K. \& Kirshtein, J. (2000). Novel bacterial and archaeal lineages from an in situ growth chamber deployed at a Mid-Atlantic Ridge hydrothermal vent. Appl Environ Microbiol 66, 3798-3806.

Rueter, P., Rabus, R., Wilkes, H., Aeckersberg, F., Rainey, F. A., Jannasch, H. W. \& Widdel, F. (1994). Anaerobic oxidation of hydrocarbons in crude oil by new types of sulphate-reducing bacteria. Nature 372, 455-458.

Saitou, N. \& Nei, M. (1987). The neighbor-joining method: a new method for reconstructing phylogenetic trees. Mol Biol Evol 4 , 406-425.

Stetter, K. O., Huber, R., Blochl, E., Kurr, M., Eden, R. D., Fielder, M., Cash, H. \& Vance, I. (1993). Hyperthermophilic archaea are thriving in deep North Sea and Alaskan oil reservoirs. Nature 365 , 743-745.

Wagner, M., Roger, A. J., Flax, J. L., Brusseau, G. A. \& Stahl, D. A. (1998). Phylogeny of dissimilatory sulfite reductases supports an early origin of sulfate respiration. J Bacteriol 180, 2975-2982.

Widdel, F. \& Pfennig, N. (1981). Studies on dissimilatory sulfatereducing bacteria that decompose fatty acids. I. Isolation of new sulfate-reducing bacteria enriched with acetate from saline environments. Description of Desulfobacter postgatei gen. nov., sp. nov. Arch Microbiol 129, 395-400.

Zhilina, T. N., Zavarzin, G. A., Rainey, F. A., Pikuta, E. N., Osipov, G. A. \& Kostrikina, N. A. (1997). Desulfonatronovibrio hydrogenovorans gen. nov., sp. nov., an alkaliphilic, sulfate-reducing bacterium. Int J Syst Bacteriol 47, 144-149. 